\title{
Implementation Of Blended Learning Model In Pandemi Era Covid- 19 In South Sulawesi Province
}

\author{
Fitri Yanty Muchtar ${ }^{1}$, Nasrah Nasrah $^{2}$, Muhammad Ilham $S^{3}$, Fitri Wahyuni ${ }^{4}$ \\ \{fitriyantymuchtar@unismuh.ac.id ${ }^{1}$ \} \\ Pendidikan Guru Sekolah Dasar, Universitas Muhammadiyah Makassar, Indonesia ${ }^{1234}$
}

\begin{abstract}
The Covid-19 Pandemic era has an impact on the learning process in schools where the learning process must apply health protocols, so an appropriate learning strategy is needed, namely, Blended Learning. Blended learning is a strategy that combines offline and online learning to minimize the number of Covid-19 transmissions. This study aims to describe the implementation of the Covid-19 era blended learning strategy in South Sulawesi Province. This research was conducted using a survey method by taking 62 elementary school teachers as respondents - data collection using an online question-based questionnaire. The data analysis technique used in this research is descriptive analysis. Based on the results of a survey conducted by researchers, it shows that the application of blended learning in South Sulawesi is still ineffective in terms of (1) The level of educators' understanding of the blended learning strategy has only reached 40\%. (2) Implementation encountered many obstacles, namely the internet network and the availability of quota, which reached $88 \%$. (3) Educators hope that they will be provided with facilities such as quotas and adequate systems as well as training on the application of the blended learning strategy in elementary schools.
\end{abstract}

Keywords: Blended Learning, Implementation, Covid-19.

\section{Introduction}

Currently, The world is facing the Covid-19 pandemic, which has an impact on all activities, one of which is in the education sector in Indonesia, including the affected South Sulawesi province, which makes us unable to meet face to face in class and deliver lesson material directly, so we have to implement distance learning (Online) style. In the education system in the new normal era in Indonesia, knowledge will be implemented based on the guidelines for the implementation of learning in the 2020/2021 academic year during the COVID-19 pandemic, by prioritizing health protocols [1]. Based on this decision, an appropriate learning strategy is needed, namely, Blended Learning. Blended learning is a strategy that combines offline and online knowledge to minimize the number of Covid-19 transmissions. Over the past two decades, higher education institutions have increasingly adopted blended learning for various reasons and the pedagogical concept configures itself as the new normal in higher education [2].

Blended learning is a teaching and learning strategy that aims to achieve learning objectives by combining class-based/face-to-face learning with technology and information-based education conducted online[3]. With blended learning facilities, students can learn flexibility whenever and wherever they are. Besides that, students can also interact easily with their teachers and get sources of information and materials and teaching media both in class and 
outside the classroom through the help of information technology online (online ) quickly. This is in line with Jowsey's research results showing that blended learning can positively affect and impact student achievement, primarily when used to manage and support distance education [4]. $\mathrm{Li}$ also supports this opinion. Blended learning can effectively increase the positive and emotional knowledge of students [5]. Blended learning makes it easy for educators to do learning because, in the application of blended learning, educators can combine various methods, models, and strategies in learning so that learning materials and objectives can be adequately conveyed and effectively[6]. Therefore, blended learning can be used as a teaching method in education at this time of the Covid-19 pandemic.

In the era of the Covid-19 pandemic, we are required to implement the Blended Learning strategy. Blended learning is a real opportunity to create learning experiences in the Covid-19 pandemic era that can provide the right education at the right time and in the right place for each individual, not only at work but at school, university, and even at home. It can be truly universal, crossing global boundaries and uniting groups of learners across different cultures and time zones. In this context, blended learning could be one of the most significant developments of the 21 st century.

There are still several obstacles, including inadequate network problems, internet quota, not having devices (cellphones, laptops, etc.), and there are still some students who don't know how to use a useful learning application. In the aspect of operating blended learning for users, there are still some obstacles, such as there are still teachers and students who have not been able to function blended learning properly [7].

Based on the constraints found, it is necessary to evaluate the implementation of blended learning. The evaluation activity on the performance of blended learning in the province of South Sulawesi at several elementary schools aims to collect data and then analyze the data so that the results of the analysis can be used for consideration of deciding on the object being evaluated.

\section{Research Methods}

This research was conducted using a survey method by taking 59 teachers and three primary school principals in the regency/city of South Sulawesi Province as respondents. This data collection uses a questionnaire based on the google form. This data collection was carried out in July 2020. The data analysis technique used in this study was descriptive analysis. The following is the questionnaire instrument for data collection:

Table 1. Questionnaire instrument for data collection:.

\begin{tabular}{clll}
\hline No & \multicolumn{1}{c}{ Question } & \multicolumn{1}{c}{ Coise } \\
\hline 1 & As Educators and Education Personnel in Elementary & a. No \\
Schools, Do You Know the Blended Learning Model? & b. Yes \\
2 & $\begin{array}{l}\text { As Educators and Education Personnel in Elementary } \\
\text { Schools, What is the Blended Learning Model? }\end{array}$ & \\
3 & $\begin{array}{l}\text { As Educators and Education Personnel in Elementary } \\
\text { Schools, Do you have any obstacles in applying the Blended } \\
\text { Learning Model? }\end{array}$ & $\begin{array}{l}\text { a. No Yes } \\
\text { What are your obstacles in applying the Blended Learning } \\
\text { Model? }\end{array}$ & $\begin{array}{l}\text { a. Quota } \\
\text { b. Internet Network }\end{array}$
\end{tabular}




\section{Results and Discussion}

The implementation of the Blended Learning strategy during the Covid-19 pandemic at elementary schools in South Sulawesi consists of: (1) Knowledge of Blended Learning, (2) obstacles in implementing the Blended Learning Strategy (3) The expected solution in the Blended Learning Strategy. Based on the results of the survey that was conducted, data analysis was then carried out. The results of data analysis can be described as follows:

\subsection{Knowledge Of Blended Learning}

As an Elementary School Educator, do you know the blended learning strategy? Based on the results of this survey, data was found: $95 \%$ know the blended learning strategy, and $5 \%$ do not know the blended learning strategy. Then these results were confirmed again in relation to the understanding of blended learning. By using an assessment scale, the following data were obtained:

a) $40 \%$ Got it

b) $44 \%$ Lack of Understanding

c) $16 \%$ Don't Understand

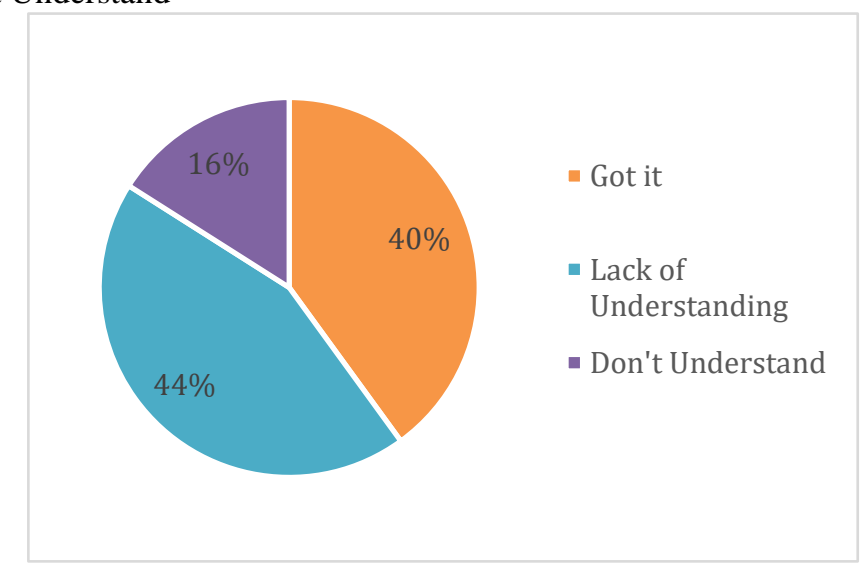

Fig. 1. Knowledge of Blended Learning.

This shows that $40 \%$ understand the application of the blended learning strategy, $44 \%$ do not understand, and $16 \%$ do not understand the application of the blended learning strategy. The teacher's understanding of blended learning is still lacking; the dominant teacher's answer 
indicates this is not appropriate in defining blended learning as mixed learning but rather online learning.

\subsection{Constraints in implementing the Blended Learning Strategy}

As an Educator in an Elementary School, Do you have any obstacles in implementing the blended learning strategy? Based on the results of this survey, it was found that data: $90 \%$ had problems, and 30\% had no issues in implementing blended learning. Then these results were confirmed again concerning what obstacles were faced in the implementation of blended learning, using a rating scale, obtained data:
a) $43 \%$ Quota
b) $45 \%$ Internet Network
c) $10 \%$ No Handphone
d) $2 \%$ Don't understand IT

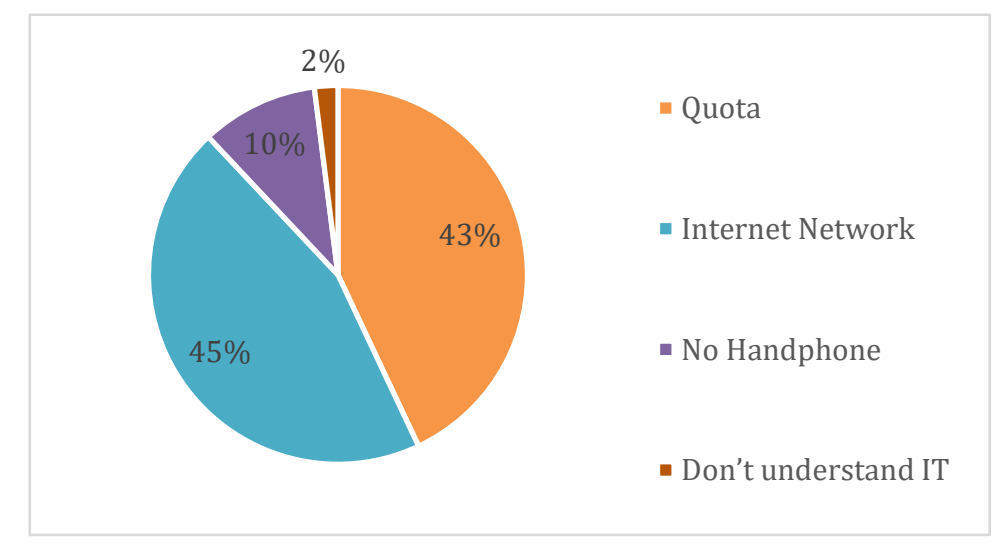

Fig. 2. Constraints in implementing the Blended Learning Strategy.

The figure indicates that the application of blended learning still faces many obstacles, including the most significant obstruction being $45 \%$ of the internet network, $43 \%$ of quota facilities, $10 \%$ do not have cellphones, and $2 \%$ do not understand how to implement Information and Technology Science (IT).

\subsection{The expected solution in the Blended Learning Strategy}

If you are constrained by implementing the blended learning strategy, do you need solutions related to these constraints? Based on the results of this survey, data was found: $97 \%$ need a solution, and 3\% do not need a solution in applying blended learning. Then these results were confirmed again concerning the desired resolution in the implementation of blended learning. By using a rating scale, the data obtained:

a) $52 \%$ Facilities

b) $26 \%$ Training 
c) $22 \%$ There is no solution

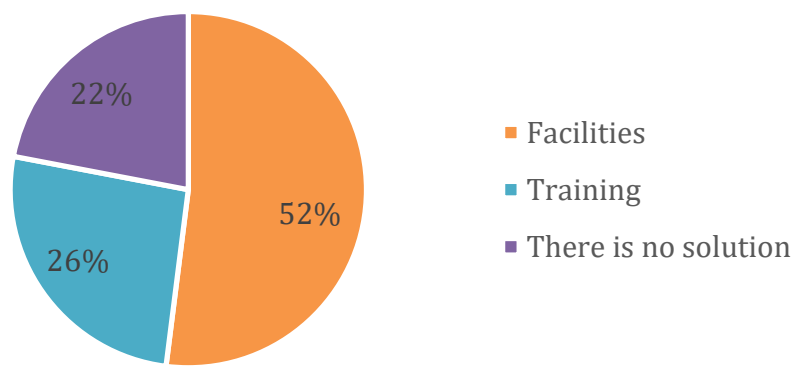

Fig. 3. The solution expected in implementing the Blended Learning Strategy

This figure indicates that the application of blended learning still faces many obstacles, including the most significant obstruction being $45 \%$ of the internet network, $43 \%$ of quota facilities, $10 \%$ do not have cellphones, and $2 \%$ do not understand how to implement Technology (IT) and information.

\section{Conclusion}

Teachers' understanding of blended learning is still lacking, and the application of blended learning still faces many obstacles, including the biggest obstacle is the quota facility and internet network. Teachers hope that they will be provided with facilities such as quotas and adequate systems as well as given training on how to implement blended learning.

Acknowledgments. We convey to all those who have contributed to our research with the topic of the implementation of the blended learning strategy in the Covid-19 pandemic era in South Sulawesi province so that the results of this study can be used as information for educators and education personnel and the community.

\section{References}

[1] Kemendikbud. "UU No.1/Kb/2020 Panduan Penyelenggaraan Pembelajaran Pada Tahun Ajaran 2020/2021 Dan Tahun Akademik 2020/2021 Di Masa Pandemi Corona Virus Disease 2019 (Covid19)". Jakarta: Kemendikbud, 2020.

[2] C. Dziuban, C. R. Graham, P. D. Moskal, A. Norberg, and N. Sicilia, "Blended learning: the new normal and emerging technologies," Int. J. Educ. Technol. High. Educ., vol. 15, no. 1, pp. 1-16, 2018, doi: 10.1186/s41239-017-0087-5.

[3] D. N. Wardani, A. J. E. Toenlioe, and A. Wedi, "Daya Tarik Pembelajaran Di Era 21 Dengan Blended Learning," J. Kaji. Teknol. Pendidik., vol. 1, no. 1, pp. 13-18, 2018. 
[4] T. Jowsey, G. Foster, P. Cooper-Ioelu, and S. Jacobs, "Blended learning via distance in preregistration nursing education: A scoping review," Nurse Educ. Pract., vol. 44, no. October 2018, p. 102775, 2020, doi: 10.1016/j.nepr.2020.102775.

[5] C. Li, J. He, C. Yuan, B. Chen, and Z. Sun, "The effects of blended learning on knowledge, skills, and satisfaction in nursing students: A meta-analysis," Nurse Educ. Today, vol. 82, no. June, pp. 5157, 2019, doi: 10.1016/j.nedt.2019.08.004.

[6] I. K. Widiara, "Blended Learning sebagai Alternatif Pembelajaran di Era Digital," Purwadita, vol. 2, no. 2 , pp. 60-56, 2018.

[7] D. G. H. Divayana, "Evaluasi pelaksanaan blended learning di SMK TI Udayana menggunakan model CSE-UCLA," J. Pendidik. Vokasi, vol. 7, no. 1, p. 64, 2017, doi: 10.21831/jpv.v7i1.12687. 